\title{
Analisis Pelayanan Angkutan Kota Trayek Terminal Tambak Osowilangun
}

\author{
Analysis of City Transportation Services Route to Terminal Tambak \\ Osowilangun
}

\author{
Fitri Rohmah Widayanti ${ }^{1}$ Amanda Ristriana Pattisinai ${ }^{2}$ \\ ${ }^{1,2}$ Program Vokasi, Universitas Negeri Surabaya \\ Jln. Ketintang Surabaya. Telp: (031) 8280383. \\ Email : fitriwidayanti@unesa.ac.id
}

\begin{abstract}
Abstrak
Surabaya merupakan kota dengan wilayah administratif yang cukup luas. Hal tersebut menuntut adanya sarana dan prasarana transportasi yang memadai untuk menjangkau seluruh sudut kawasan kota. Menurunnya jumlah pengguna angkutan kota di Kota Surabaya pada trayek Terminal Tambak Osowilangun ditunjukkan dengan meningkatnya pengguna moda angkutan pribadi disepanjang rute trayek Tambak Osowilangun. Hal tersebut diikuti dengan menunrunnya jumlah armada angkutan kota trayek Terminal Tambak Osowilangun yang beroperasi. Permasalahan tersebut menjadi tujuan peneliti untuk mengetahui penilaian penumpang terhadap kinerja angkutan kota trayek terminal Tambak Osowilangun dan mengetahui faktor pelayanan yang dianggap penting oleh penumpang, tetapi belum baik dalam pelaksanaanya. Penelitian dilakukan dengan menggunakan metode survey dengan responden yaitu pengguna angkutan kota trayek terminal Tambak Osowilangun. Data yang didapat diolah dengan Analisis Kuadran. Hasil analisis kuadran menunjukan bahwa ketersediaan moda angkutan kota menjadi faktor yang menempati kuadran A dimana berarti penumpang merasa faktor tersebut penting akan tetapi pelaksanaannya tidak sesuai harapan, sehingga perlu adanya perbaikan. Penambahan jumlah moda angkutan kota perlu dilakukan agar headway angkutan kota trayek Terminal Tambak Osowilangun tidak terlalu lama
\end{abstract}

Kata Kunci: Kepuasan pengguna; kinerja anguktan kota; kualitas pelayanan.

\begin{abstract}
Surabaya is a city with a fairly wide administrative area. This requires adequate transportation facilities and infrastructure to reach all corners of the city area. The decrease in the number of users of urban transportation in the city of Surabaya on the route of the Tambak Osowilangun Terminal is indicated by the increase in users of private transportation modes along the route of the Tambak Osowilangun route. This was followed by a decrease in the number of city transportation fleets operating on the Osowilangun Tambak Terminal route. This problem is the goal of the researcher to determine the passenger's assessment of the performance of city transportation on the Tambak Osowilangun terminal route and to find out the service factors that are considered important by passengers, but are not yet good in their implementation. The study was conducted using a survey method with respondents, namely users of urban transportation routes at the Tambak Osowilangun terminal. The data obtained were processed by Quadrant Analysis. The results of the quadrant analysis show that the availability of urban transportation modes is a factor that occupies quadrant A, which means that passengers feel that this factor is important but its implementation is not as expected, so improvements are needed. The addition of the number of modes of urban transportation needs to be done so that the headway of the city transportation route at the Osowilangun Tambak Terminal is not too long.
\end{abstract}

Keywords: User satisfaction; city transport performance; service quality. 


\section{PENDAHULUAN}

Transportasi memiliki peran penting dalam kegiatan manusia, karena kegiatan transportasi mempengaruhi banyak aspek dalam kehidupan manusia yang berkaitan satu sama lain (Toar, Timboeleng, and Sendow 2015)

Surabaya merupakan salah satu kota metropolitan dengan kegiatan transportasi yang cukup tinggi. Kegiatan tranportasi tersebut perlu didukung dengan prasarana dan sarana yang dapat melayani kegiatan pergerakan dengan terrtib, lancar, aman dan nyaman (Anastasia, Dwi Ari, and Agustin 2015). Untuk mengakomodir tingginya kegiatan mobilitas perkotaan perlu adanya penataan sistem transportasi yang baik. Angkutan kota merupakan salah satu sarana yang memiliki peran penting dalam mendukung sistem transportasi perkotaan (Buamona, , Dr. Ir. James Timboeleng, and , Hendriek Karongkong, ST. 2018).

Dalam proses pengambilan keputusan, perilaku pengguna jasa transportasi merupakan faktor psikologis yang menentukan (Semiun 2018). Faktor yang mempengaruhi kualitas pelayanan meliputi bentuk kualitas pelayanan (service quality), nilai kualitas yang dirasakan pengguna jasa, (perceived value) dan kepuasan terhadap pelayanan dari pengguna jasa (customer satisfaction) (Bahar 2013). Pada saat ini jumlah pengguna angkutan kota di Surabaya semakin menurun, hal tersebut dapat dilihat dari tingkat kepadatan lalu lintas yang didominasi oleh kendaraan pribadi. Hal tersebut menunjukkan bahwa pelayan yang diberikan angkutan kota di Surabaya belum memenuhi standart pelayanan, yang menyebabkan rendahnya minat masyarakat terhadap angkutan kota (Ningrum, Muchsin, and Widodo 2019)

Salah satu permasalahan terkait pelayanan angkutan kota di Surabaya adalah jumlah ketersediaan angkutan umum dalam suatu rute yang belum bisa secara maksimal mengakomodir kegiatan mobilitas masyarakat.

Permasalahan-permasalahan terkait dengan pelayanan tersebut yang menjadi faktor masyarakat cenderung memilih moda lain yang mempermudah mobilitas yaitu kendaraan pribadi.

Tujuan penilitian yang hendak dicapai adalah untuk mengetahui kualitas dari pelayanan angkutan kota rute Terminal Tambak Oso Wilangun berdasarkan kinerja angkutan kota dan kepuasan pengguna. Hasil dari penelitian diharapkan dapat memberikan masukan terkait upaya dalam peningkatan pelayanan angkutan kota bagi pengguna.

\section{Permasalahan Transportasi Kota}

Wilayah perkotaan merupakan daerah yang menjadi tempat berkumpul dari segala aktifitas penduduk dalam sektor pertanian, sektor jasa, pusat ekonomi perdagangan, pusat pemerintahan dan sektor-sektoe yang lain. Kota juga menjadi tempat kompetisi untuk berbagai kepentingan. Kota juga cenderung menjadi pilihan masyarakat sebagai sumber penghidupan social dan ekonomi, hal tersebut menjadi pemicu banyaknya pemasalahan di wilayah perkotaan salah satunya yaitu permasalahan transportasi. Persoalan transportasi cenderung menyangkut pada aspek manusia dan barang dengan dengan kepentingan tertentu. Kegiatan berpindah manusia dan barang dari suatu tempat ke tempat lain menjadi "hak" bagi setiap individu dan telah dilindungi oleh Undangundang. Pada saat ini permasalahan yang sering muncul adalah wilayah perkotaan yang luas tidak diimbangi dengan fasilitas yang memadai. Sedangkan populasi di perkotaan semakin hari semakin meningkat. Hal tersebut tentunya mempengaruhi daya dukung kota yang semakin menurun apabila tidak dilakukan suatu Tindakan perbaikan. Hal tersebut tentu akan berdampak bagi keberlangsungan kehidupan manusia dimasa yang akan dating (Idris 2012).

Aksesibilitas dalam jaringan jalan pada perkotaan menjadi indikator dari tingkat kemudahan pelayanan. Tingkat kemudahan dalam pelayanan transportasi di Surabaya yang merupakan wilayah aglomerasi perkotaan masih relative rendah. Hal tersebut ditunjukkan dengan masih banyak wilayah di kota Surabaya yang tidak dapat diakses dengan mudah menggunakan kendaraan umum.

\section{Standart Pelayanan Angkutan Kota}

Parameter standar kualitas pelayanan angkutan umum berdasarkan Survey Research Institute (SRI), SK Direktur Jenderal Perhubungan Darat No. 687 Tahun 2002 dan World Bank yaitu: 1) frekuensi kendaraan, dikategorikan baik apabila frekuensi kendaraan lebih dari 6 kendaraan/jam; 2) waktu tunggu, dikategorikan baik apabila rata-rata waktu tunggu antara 5-10 menit; 3) waktu perjalanan dikategorikan baik yaitu dengan rata-rata antara 11,5 jam, 4) jam operasional, dikategorikan baik jika memiliki jam layanan operasional pukul 05.00-22.00 WIB; 5) jarak pencapaian halte di pusat kota antara 300-500 meter (Muryanto and Santosa 2016).

\section{Kepuasan Pengguna}

Kepuasan pengguna merupakan perbedaan antara harapan dengan hasil dari kinerja yang dirasakan yang dirasakan oleh pengguna. Ketatnya dunia persaingan bisnis menuntut penyedia jasa untuk dapat bertahan, eh karena itu penyedia jasa harus berusaha secara maksimal sehingga konsumen tidak berpindah. Upaya yang dapat dilakukan oleh penyedia jasa untuk menjaga kepuasan konsumen 
dapat dilakukan dengan melakukan identifikasi mengenai target konsumen. Selalu memantau terkait dengan tingkat harapan pengguna terhadap produk jasa atau kualitas produk jasa yang disediakan. Mengetahui strategi yang harus dilakukan untuk menjaga kualitas produk jasa yang dihasilkan untuk pengguna. Memahami metode-metode pengukuran untuk mendapat umpan balik guna mempertahankan kepuasan pengguna (Muis, Fathoni, and Minarsih 2018).

Penelitian terkait dengan kepuasan penumpang telah dilakukan mulai pertengahan 1960. Kepuasan merupakan penghubung dari kualitas pelayanan dan harapan pengguna dimana kepuasan pengguna adalah faktor penting yang berkaitan dengan keputusan kesetiaan pengguna terhadap suatu pelayanan yang diberikan (van Lierop, D., Badami, M., \& El-Geneidy 2021)

\section{METODE}

Dalam penelitian dijelaskan pengaruh dari komponen-komponen kualitas layanan angkutan kota terhadap penilaian kepuasan penumpang angkutan kota rute Terminal Tambak Oso Wilangun. Hubungan antar indikator kinerja pelayanan angkutan kota diukur menggunakan metode IPA yang kemudian akan digambarkan dalam bentuk diagram kartesius.

Objek dalam penelitian adalah kinerja pelayanan dari angkutan kota yang ditinjau dari standart world bank.

\section{Metode IPA}

Metode Important performance analysis (IPA) atau yang biasa juga disebut analisis kuadran mengukur tingkat penilaian kinerja berdasarkan responden yang kemudian hasil penilaian tersebut akan digambarkan kedalam empat kuadran yang dapat dilihat pada gambar 1 (Purnawan and Sanjaya 2017).

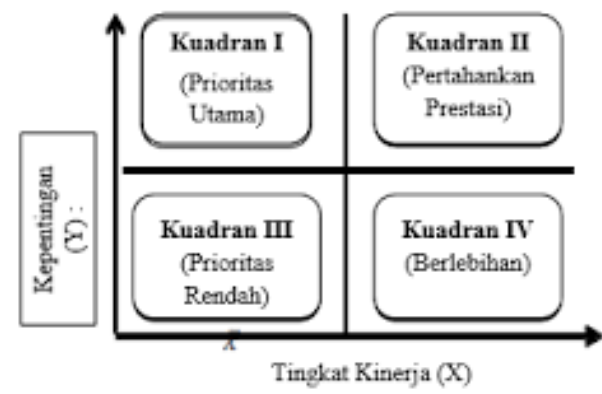

Gambar 1. Diagram Kartesius Analisis Kepentingan dan Kinerja

Keterangan tiap-tiap kuadran dari gambar 1 yaitu Kuadran I : prioritas utama perbaikan, Kuadran II: pertahankan prestasi, Kuadran III : prioritas rendah, dan kuadran IV : berlebihan. Dalam penelitian importance yaitu penilaian dari tingkat kepentingan/ harapan penumpang terhadap kualitas pelayanan angkutan kota dan Performance adalan penilaian kepuasan penumpang terhadap kinerja angkutan kota.

Untuk mengetahui kesesuaian antara kepuasan dan harapan untuk setiap variabel yang ada, akan dihitung dengan menggunakan persamaan berikut :

$$
T k i=\frac{X i}{Y i} \times 100 \% \ldots \ldots \ldots \ldots \ldots \ldots[2]
$$

Keterangan :

Tki : Tingkat Kesesuaian Responden

$\mathrm{Xi}$ : Skor Penilaian Kinerja

Yi :Skor Penilaian Kepentingan Pengguna Jasa Dalam penelitian ini survey dilaksanakan dengan menyebarkan kuisioner yang telah disusun dan kemudian diisi oleh responden. Adapun pengambilan sampel untuk penelitian dilakukan menggunakan metode Slovin (Faisal, Herijanto, and Gde 2020). Adapun rumus perhitungan dari metode slovin adalah sebagai berikut :

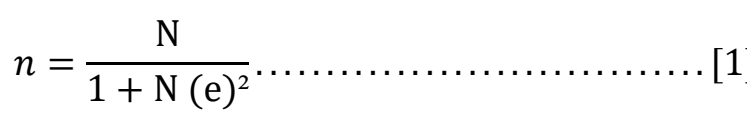

Keterangan :

$\mathrm{n}=$ Jumlah sampel

$\mathrm{N}=$ Jumlah populasi

$\mathrm{e} \quad=$ Persen tingkat kesalahan, konstanta $(0.1$ atau $10 \%$ )

\section{Skala Likert}

Dalam penelitian penilaian dalam kuesioner menggunakan skala 5 tingkat (Likert) yang terdiri dari sangat penting, penting, cukup penting, kurang penting dan tidak penting, dengan bobot penilaian : Jawaban sangat penting bobot 5 , Jawaban penting bobot 4, Jawaban cukup penting bobot 3, Jawaban kurang penting bobot 2, dan Jawaban tidak penting bobot 1 .

\section{HASIL DAN PEMBAHASAN}

Berdasarkan survey lapangan diketahui angkutan kota di Surabaya yang melayani rute Terminal Tambak Oso Wilangun dapat dilihat pada tabel 1. 
Tabel 1. Angkutan kota rute terminal tambak osowilangun

\begin{tabular}{lll}
\hline No & Angkutan Umum & Rute \\
1 & Bus Kota P6 & $\begin{array}{l}\text { T OW - Kupang-Diponegoro - } \\
\text { A.Yani - Purabaya }\end{array}$ \\
\hline 2 & Damri P8 & $\begin{array}{l}\text { T OW - Tol Panjang - } \\
\text { Purabaya }\end{array}$ \\
\hline 3 & Lyn WK & T O W - Keputih \\
\hline 4 & Lyn RDK & $\begin{array}{l}\text { Dukuh Kupang - T O W - } \\
\text { Benowo }\end{array}$ \\
\hline 5 & Lyn PTG & Pasar Turi - Gresik \\
\hline 6 & Lyn SG & Surabaya - Gresik \\
\hline
\end{tabular}

Angkutan kota dengan rute Terminal Tambak Osowilangun pada tabel 1 tersebut menjadi objek penelitian melalui pelaksanaan survey terkait kinerja angkutan kota. Karena keterbatasan waktu dan tenaga, dalam pengambilan data lapangan, maka survey hanya dilakukan satu hari pada semua rute yang melewati terminal Tambak Osowilangun selama enam jam yaitu dua jam peak hour pagi (06.00-08.00 WIB), dua jam off peak (11.00-13.00 WIB), dan dua jam peak hour sore (16.00-18.00).

\section{Analisis Kinerja Angkutan Kota}

Berdasarkan hasil survey kinerja angkutan kota rute Terminal tambak Osowilangun didapat hasil analisis terkait headway dari angkutan kota yang dapat dilihat pada tabel 2 .

Tabel 2. Headway rata-rata angkutan kota

$\begin{array}{cccc}\text { Angkutan } & \begin{array}{c}\text { Headway } \\ \text { Kota }\end{array} & \begin{array}{c}\text { Rata-rata } \\ \text { (Menit) }\end{array} & \begin{array}{c}\text { Standart } \\ \text { (Menit) }\end{array} \quad \text { Keterangan }\end{array}$

\begin{tabular}{|c|c|c|c|}
\hline P6 & 42 & \multirow{6}{*}{$5-10$} & $\begin{array}{c}\text { Kurang } \\
\text { Baik }\end{array}$ \\
\hline P8 & 26 & & $\begin{array}{c}\text { Kurang } \\
\text { Baik }\end{array}$ \\
\hline WK & 8 & & Baik \\
\hline RDK & 53 & & $\begin{array}{c}\text { Kurang } \\
\text { Baik }\end{array}$ \\
\hline PTG & 5 & & Baik \\
\hline SG & 2 & & Baik \\
\hline
\end{tabular}

Berdasarkan tabel 2 diketahui kinerja headway dari angkutan kota yang belum memenuhi standart ideal headway 5-10 menit yaitu angkutan kota P6, P8, dan RDK. Headway angkutan kota tersebut masih sangat tinggi yaitu 42 menit, 26 menit dan 53 menit. Hasil analis kinerja untuk frekuensi kendaraan/jam angkutan kota rute Terminal Tambak Oso Wilangun dalam kondisi Off Peak dapat dilihat pada tabel 3.
Tabel 3. Frekuensi kendaraan/jam pada off peak siang (11.00-13.00 WIB)

\begin{tabular}{|c|c|c|c|}
\hline $\begin{array}{l}\text { Angkutan } \\
\text { Umum }\end{array}$ & $\begin{array}{c}\text { Jumlah } \\
\text { Angkutan } \\
\text { Umum Lewat } \\
\text { (Kendaraan/jam) }\end{array}$ & $\begin{array}{l}\text { Standar } \\
\text { Off Peak }\end{array}$ & Keterangan \\
\hline P6 & 2 & \multirow{6}{*}{$\begin{array}{c}6 \\
\text { kend/jam }\end{array}$} & $\begin{array}{l}\text { Di bawah } \\
\text { Standar }\end{array}$ \\
\hline P8 & 3 & & $\begin{array}{c}\text { Di bawah } \\
\text { Standar }\end{array}$ \\
\hline WK & 9 & & Baik \\
\hline RDK & 1 & & $\begin{array}{c}\text { Di bawah } \\
\text { Standar }\end{array}$ \\
\hline PTG & 11 & & Baik \\
\hline SG & 25 & & Baik \\
\hline
\end{tabular}

Berdasarkan tabel 3 diketahui 50\% kinerja frekuensi kendaraan/jam angkutan kota rute Terminal Tambak Oso Wilangun pada kondisi Off Peak belum memenuhi standart yaitu 12 kendaraan/jam.

Hasil analis kinerja untuk frekuensi kendaraan/jam angkutan kota rute Terminal Tambak Oso Wilangun pada kondisi Peak Hour pagi dapat dilihat pada tabel 4.

Tabel 4. Frekuensi kendaraan/jam pada peak hour pagi (06.00-08.00 WIB)

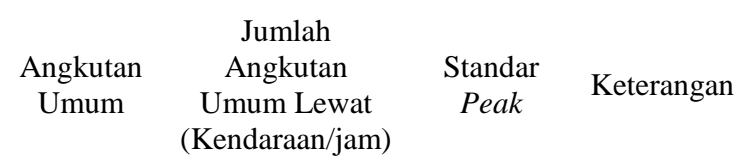

\begin{tabular}{|c|c|c|c|}
\hline P6 & 2 & \multirow{6}{*}{$\begin{array}{c}12 \\
\text { Kend/jam }\end{array}$} & $\begin{array}{c}\text { Di bawah } \\
\text { Standar }\end{array}$ \\
\hline P8 & 2 & & $\begin{array}{c}\text { Di bawah } \\
\text { Standar }\end{array}$ \\
\hline WK & 11 & & $\begin{array}{c}\text { Di bawah } \\
\text { Standar }\end{array}$ \\
\hline RDK & 4 & & $\begin{array}{c}\text { Di bawah } \\
\text { Standar }\end{array}$ \\
\hline PTG & 15 & & Baik \\
\hline SG & 32 & & Baik \\
\hline
\end{tabular}

Berdasarkan tabel 4 diketahui lebih dari 50\% kinerja frekuensi kendaraan/jam angkutan kota rute Terminal Tambak Oso Wilangun pada kondisi Peak Hour masih belum memenuhi standart yaitu 12 kendaraan/jam

Hasil analis kinerja untuk frekuensi kendaraan/jam angkutan kota rute Terminal Tambak Oso Wilangun pada kondisi peak hour sore dapat dilihat pada tabel 5. 
Tabel 5. Frekuensi kendaraan/jam pada peak hour sore (16.00-18.00 WIB)

$\begin{array}{cccc}\text { Angkutan } & \begin{array}{c}\text { Jumlah } \\ \text { Angkutan }\end{array} & \text { Standar } & \\ \text { Umum } & \text { Umum Lewat } & \text { Peak } & \text { Keterangan } \\ & \text { (Kendaraan/jam) } & & \end{array}$

\begin{tabular}{|c|c|c|c|}
\hline P6 & 2 & \multirow{6}{*}{$\begin{array}{c}12 \\
\text { Kend/jam }\end{array}$} & $\begin{array}{c}\text { Di bawah } \\
\text { Standar }\end{array}$ \\
\hline P8 & 3 & & $\begin{array}{c}\text { Di bawah } \\
\text { Standar }\end{array}$ \\
\hline WK & 5 & & $\begin{array}{c}\text { Di bawah } \\
\text { Standar }\end{array}$ \\
\hline RDK & 1 & & $\begin{array}{c}\text { Di bawah } \\
\text { Standar }\end{array}$ \\
\hline PTG & 9 & & $\begin{array}{l}\text { Di bawah } \\
\text { Standar }\end{array}$ \\
\hline SG & 23 & & Baik \\
\hline
\end{tabular}

Berdasarkan tabel 5 diketahui hanya angkutan kota SG yang kinerja frekuensi kendaraan/jam memenuhi standart yaitu 12 kendaraan/jam.

\section{Analisis Kepuasan Pengguna}

Survey kepuasan pengguna dilakukan kepada responden. Dimana responden pada penelitian ini adalah pengguna, angkutan kota rute Terminal Tambak Osowilangun. Adapun hasil analisis pengisian kuesioner oleh pengguna tercantum pada gambar 2.

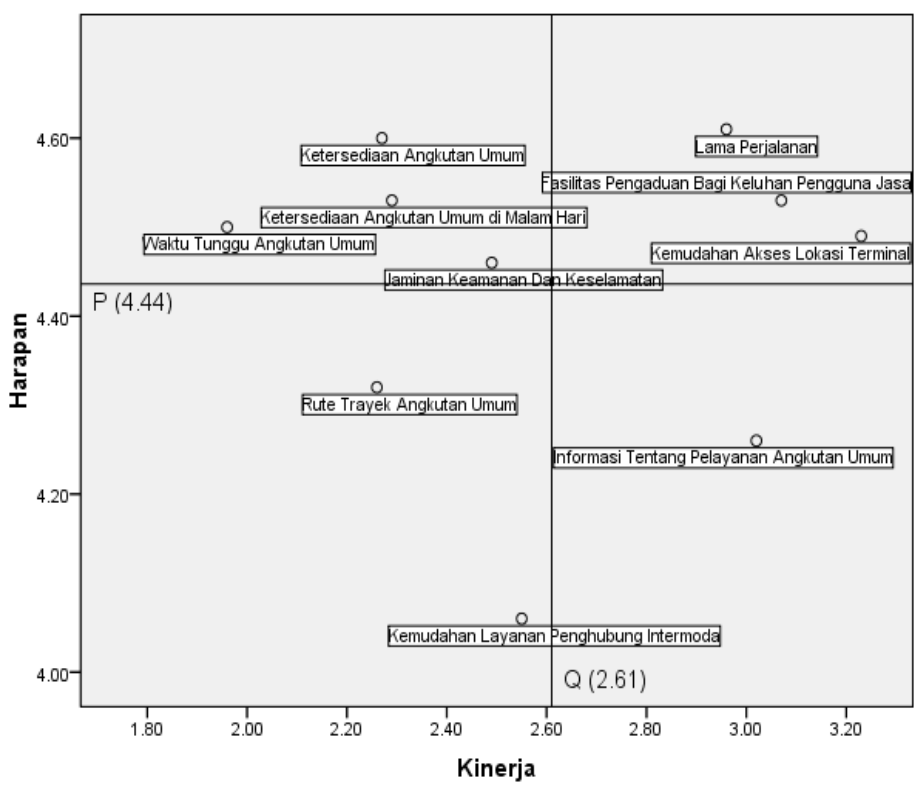

Gambar 2. Diagram Kartesius Kartesius Tingkat Harapan Dan Tingkat Kinerja Penumpang Pengguna Angkutan Kota

Berdasarkan gambar 2 diketahui faktor-faktor yang berada pada kuadran A dimana hasil penilaian pengguna menunjukkan hasil kinerja pelayanan belum sesuai dengan harapan pengguna angkutan kota sehingga masih perlu dilakukan perbaikan. Faktor-faktor yang masih perlu diperbaiki yaitu ketersediaan angkutan umum, ketersediaan angkutan umum di malam hari, waktu tunggu angkutan umum, dan jaminan keamanan dan keselamatan.

\section{SIMPULAN}

Berdasarkan hasil analisis survey yang telah dilakukan diketahui bahwa kinerja angkutan kota rute Terminal Tambak Osowailangun masih jauh dari standart world bank. Berdasarkan standart world bank headway ideal angkutan kota adalah 5-10 menit, berdasarkan hasil survey diketahui headway rata-rata untuk seluruh angkutan kota dengan rute Terminal Tambak Osowilangun adalah 23 menit. Hasil analisis survey terkait dengan frekuensi kendaraan/jam untuk semua angkutan kota trayek Terminal Tambak Osowailangun juga menunjukkan belum memenuhi standart word bank yaitu 12 kendaraan/jam baik pada kondisi peak hour maupun off peak. Berdarsarkan hasil analisis yang menunjukkan headway dan frekuensi jumlah kendaraan/jam yang masih belum memenuhi standart, dapat disimpulkan bahwa kurangnya ketersediaan jumlah moda angkutan kota trayek Terminal Tambak Osowailangun. Hal tersebut diperkuat dengan hasil analisis kepuasan pengguna angkutan kota trayek C. Dimana hasil analisis kuadran menunjukkan faktor ketersediaan angkutan umum baik pagi atau malam hari berada pada kuadarn A dimana kinerja pelayanan faktor tersebut belum memenuhi harapan pengguna angkutan kota, sehingga perlu dilakukan perbaikan. Hasil analisis kepuasan pengguna angkutan kota trayek Terminal Tambak Osowilangun juga menunjukkan bahwa waktu tunggu angkutan umum merupakan faktor yang hasil kinerjannya belum memenuhi harapan pengguna dan diperlu dilakukan perbaikan. Hal tersebut berkaitan dengan hasil analisis dari survey kinerja headway dari angkutan kota trayek Terminal Tambak Osowilangun yang masih cukup tinggi dengan rata-rata headway 23 menit.

Saran perbaikan yang dapat dilakukan berdasarkan hasil penelitian yaitu dengan menambah moda angkutan kota trayek Terminal Tambak Osowilangun. Dengan adanya penambahan jumlah moda diharapkan dapat mengakomodir kegiatan mobilitas masyarakat Surabaya untuk trayek Terminal Tambak Osowilangun. Penambahan moda juga dapa mempersingkat waktu tunggu angkutan umum (headway). 


\section{REFERENSI}

Anastasia, Anastasia, Ismu Dwi Ari, and Imma Agustin. 2015. "Evaluasi Kinerja Pelayanan Angkutan Kota Di Kota Palu (Studi Kasus Trayek Mamboro Manonda Line B2)." Indonesian Green Technology Journal 4(3): 61-67.

Bahar, Taslim. 2013. "Kualitas Pelayanan Dan Loyalitas Penggunaan Ojek Sepedamotor Sebagai Angkutan Umum Penumpang Perkotaan." Mektek 15(2): 109-18. http://jurnal.untad.ac.id/jurnal/index.php/Mekt ek/article/view/2069/1299.

Buamona, Muhammad Syaiful, DEA, Dr. Ir. James Timboeleng, and MT , Hendriek Karongkong, ST. 2018. "ANALISIS PELAYANAN TRANSPORTASI ANGKUTAN KOTA DI KOTA TERNATE." (14): 63-65.

Faisal, Naufal Yasir, Wahju Herijanto, and Agung Gde. 2020. "Analisis Kinerja Transportasi BRT Damri Pemadu Moda Kota Makassar Terhadap Segi Kepuasan Penumpang." 9(2).

Idris, Zil Hardi. 2012. "Arah Kebijakan Penyelenggaraan Transportasi Perkotaan " Pasca Penetapan Keistimewaan Diy." Simposium Nasional RAPI XI FT: 55-60.

van Lierop, D., Badami, M., \& El-Geneidy, A. 2021. "What Influences Satisfaction and Loyalty in Public Transport? A Review of the Literature." Angewandte Chemie International Edition, 6(11), 951-952. 38: 2013-15.

Muis, Abdul, Aziz Fathoni, and M M Maria M
Minarsih. 2018. "Analisis Faktor-Faktor Yang Mempengaruhi Kepuasan Konsumen Terhadap Pengguna Tranportasi Go-Jek Di Semarang." Jornal Ekonomi dan Bisnis 4(4): 1-18.

Muryanto, D., and R. Santosa. 2016. "Kajian Operasional Bus Rapid Transit (BRT) Koridor Utara Selatan Kabupaten Sidoarjo." Prosiding Temu Ilmiah IPLBI 2016: 27-30.

Ningrum, S.w., S. Muchsin, and Rp Widodo. 2019.

"Evaluasi Kinerja Pelayanan Dinas

Perhubungan Dalam Bidang Transportasi Umum Perkotaan." EVALUASI KINERJA PELAYANAN DINAS PERHUBUNGAN DALAM BIDANG TRANSPORTASI UMUM PERKOTAAN (Studi 13(2): 53-61.

Purnawan, and Febryan Sanjaya. 2017. "Important Performance Analysis as a Strategic Planning Technique in Bus Rapid Transit Development Program." International Journal of Civil Engineering and Technology 8(10): 805-13.

Semiun, Oktovianus Edvict. 2018. "Pengaruh Kualitas Pelayanan Angkutan Kota Terhadap Kepuasan Dan Loyalitas Penumpang Di Kota Kupang." Rekayasa Sipil 12(1): 39-49.

Toar, Jurike Ireyne, James A. Timboeleng, and Theo K. Sendow. 2015. "Analisa Pemilihan Moda Angkutan Kota Manado - Kota Gorontalo Menggunakan Model Binomial-Logit-Selisih." Jurnal Sipil Statik 3(1): 27-37. https://ejournal.unsrat.ac.id/index.php/jss/artic le/view/6790. 